Original Paper http://ajol.info/index.php/ijbcs http://indexmedicus.afro.who.int

\title{
Impacts of artisanal and small-scale gold mining on soils in northern regions of Côte d'Ivoire: cases of Boundiali, Korhogo and Tengrela
}

\author{
Jean C. A. BEDA ${ }^{1}$, Jean-Marie P. OUATTARA ${ }^{1}$, Aman MESSOU ${ }^{1 *}$ \\ and Lacina COULIBALY ${ }^{1,2}$ \\ ${ }^{1}$ Laboratory of Environment and Aquatic Biology, Department of Sciences and Environment Management, \\ NANGUI ABROGOUA University, 02 BP 801, Abidjan 02, Côte d'Ivoire. \\ ${ }^{2}$ University of Man, BPV 20, Man, Côte d'Ivoire. \\ "Corresponding author; E-mail: messouaman@yahoo.fr; Tel. (+225) 07-07-44-29-95
}

Received: 04-02-2021

Accepted: 20-06-2021

Published: $30-06-2021$

\begin{abstract}
The development artisanal and small-scale gold mining in recent years in Côte d'Ivoire could pose a risk to soils and health of local communities. This study aimed at assessing the impacts of artisanal and smallscale gold mining on the soils in the areas in the northen localities (Boundiali, Korhogo and Tengrela) of Côte d'Ivoire, where those activities are accentuated. Field observation and physico-chemical parameters analysis (potential hydrogen $(\mathrm{pH})$, cation exchange capacity $(\mathrm{CEC})$, organic matter $(\mathrm{OM})$ ) and pollutants (mercury $(\mathrm{Hg})$, copper $(\mathrm{Cu})$, zinc $(\mathrm{Zn})$, arsenic $(\mathrm{As})$ and cyanide $(\mathrm{CN}))$ in soil samples were carried out. The results indicate that artisanal gold mining create soils erosion and consequently, soil structure destruction. Trace metals concentrations were $0.0001-0.0051 \mathrm{mg} / \mathrm{kg}(\mathrm{Hg}), 0.002-0.32 \mathrm{mg} / \mathrm{kg}(\mathrm{CN}), 18.90-73.10 \mathrm{mg} / \mathrm{kg}(\mathrm{Cu})$, $16.40-50.1 \mathrm{mg} / \mathrm{kg}$ (As) and 10.20-26.60 mg/kg ( $\mathrm{Zn}$ ). Geoaccumulation index (Igeo) in soils showed uncontamination for $\mathrm{Hg}$ and $\mathrm{Zn}$, uncontamination to moderate contamination for $\mathrm{Cu}$ and moderate to strong contamination for As. According to ecological risk index $\left(\mathrm{Er}^{i}\right)$, As could pose considerable to high risks to biota in study area. This study highlights serious risks to soil biota and human health, from artisanal gold mining activities. Thus, it is necessary to clean-up arsenic-contaminated soils.
\end{abstract}

(C) 2021 International Formulae Group. All rights reserved.

Keywords: Artisanal gold mining, small-scale mining, soil, trace elements.

\section{INTRODUCTION}

The extractive industry becomes the second pillar of Cote d'Ivoire economy, because of several ore deposits discovery. Adoption of attractive mining laws caused the massive establishment of mining industries (Tape et al., 2019). However, the rise of gold cost of and the last decade of socio-political crisis in Côte d'Ivoire, have accentuated artisanal gold mining activities. Those activities were practiced in 24 regions out of the 31 in Côte d'Ivoire with more than 500,000 people concerned (Goh, 2016). If artisanal gold mining practices present significant impact on the socio-economic lives of peoples and communities, it nevertheless 
represents a major environmental and human if no follow-up precautions are taken. These are the destruction of the plant cover, the depletion of water resources and the contamination of various environmental matrices (soil, air, surface water and groundwater) (Hinton et al., 2003; Ibrahim et al., 2019). Chemicals such as mercury (Hg), cyanide $(\mathrm{CN})$, zinc $(\mathrm{Zn})$, nitric acid $\left(\mathrm{HNO}_{3}\right)$ and sulfuric acid $\left(\mathrm{H}_{2} \mathrm{SO}_{4}\right)$ used in ore processing can cause enormous environmental and health damage (Hinton et al., 2003; DanBadjo et al., 2014). Furthermore, once abandoned, artisanal gold mining sites pose dangers to humans and animals through very deep wells often covered by secondary vegetation (Keita, 2003). Recent studies carried out on the artisanal mining areas of Côte d'Ivoire have revealed contamination of surface water by trace metals such as arsenic (As), cadmium $(\mathrm{Cd})$, copper $(\mathrm{Cu})$, iron $(\mathrm{Fe})$, mercury, manganese $(\mathrm{Mn})$, lead $(\mathrm{Pb})$ and zinc in Hiré (Yapi et al., 2014; Akpo et al., 2020) and Kossou (Ouatttara, 2015). In addition, Konaté (2016) detected concentrations of $\mathrm{Cu}$ $(0.82-12.21 \mathrm{mg} / \mathrm{kg}), \mathrm{Zn}(15.38-40.99 \mathrm{mg} / \mathrm{kg})$ and $\mathrm{CN}(3.22-4.79 \mathrm{mg} / \mathrm{kg})$ in the organs of fish which were far above the toxicity thresholds in the surface waters of Hiré. While most of the work has focused on the quality of water and aquatic organisms, the same cannot be said for soil quality. As soil is an important support for ecosystems, particularly terrestrial ecosystems, a degradation of its physical, chemical and biological properties affects agro-pastoral activities (ACET, 2017). Also, soil plays a filtering, buffering and transformation role between the atmosphere, groundwater and plant cover. Soil pollution can affect human health by contaminating agricultural products and water (ACET, 2017). However, knowledge of the nature of soil pollution would make it possible to plan treatment solutions. This study aimed at characterizing soil pollution and degradation by artisanal mining activities in northern localities in Côte d'Ivoire (Korhogo, Boundiali and Tengrela).

\section{MATERIALS AND METHODS}

\section{Study area}

This study was conducted in the departments of Korhogo, Boundiali and Tengrela, located in the north of Côte d'Ivoire (Figure 1). Korhogo's department with an area of $12.5 \mathrm{~km}^{2}$ is located between latitudes $9^{\circ} 00^{\prime}$ 'and $10^{\circ} 24^{\prime}$ North and longitudes $5^{\circ} 00$ 'and $6^{\circ} 24$ ' West (RGPH, 2014). Boundiali is located between latitudes $9^{\circ} 00^{\prime}$ and $10^{\circ} 00^{\prime}$ North and longitudes $6^{\circ} 00$ 'and $7^{\circ} 00^{\prime}$ West with an area of $10.7 \mathrm{~km}^{2}$ (Zagbaï et al., 2006). Regarding to Tengrela, it covers an area of $2.2 \mathrm{~km}^{2}$ and is located between latitudes $10^{\circ} 00^{\prime}$ and $11^{\circ} 00^{\prime}$ North and longitudes $6^{\circ} 00^{\prime}$ and $7^{\circ} 00^{\prime}$ West. The study area climate is tropical dry with two contrasting seasons: the rainy season (monthly rains greater than $50 \mathrm{~mm}$ ) extends from May to October and the dry season, from November to April. $800 \mathrm{~mm}$ to $1,200 \mathrm{~mm}$ of annual rainfall is recorded (Goula et al., 2007). Annual temperature in Korhogo is 26.5 ${ }^{\circ} \mathrm{C}$, that of Boundiali $26.1{ }^{\circ} \mathrm{C}$ and that of Tengrela 25 to $29{ }^{\circ} \mathrm{C}$. Soils in north of Cote d'Ivoire are of the ferralitic type, moderately and slightly desaturated under attenuated rainfall. Ferruginous and granitic soils, tropical ferruginous soils, hydromorphic soils and ferralitic soils are encountered (Brou et al., 2005).

\section{Study procedure}

Artisanal and small-scale gold mining impact on soils in Korhogo, Tengrela and Boundiali areas were studied by a field observation and an analysis of physicochemical parameters $(\mathrm{pH}, \mathrm{CEC}$, organic matter) and pollutants $(\mathrm{Hg}, \mathrm{Cu}, \mathrm{Zn}, \mathrm{As}$ and $\mathrm{CN}$ ) in soil samples.

\section{Field observations}

It permitted to have a global view of artisanal gold mining activity and the 
pressures generated on the soil. It consisted of visiting the sites and illustrated observations.

\section{Soil sampling}

The soil sampling consisted of a punctual sampling using an auger. The sampling points were selected taking into account the potential sources of soil pollution (mineral processing areas) and the spatial extent of the pollution. At each point, samples were taken at depths of $[0-20 \mathrm{~cm}],[20-40$ $\mathrm{cm}],[40-60 \mathrm{~cm}]$. A total of 108 samples, including 51 from Korhogo, 27 from Boundiali and 30 from Tengrela, were collected. The soil samples were conditioned in plastics to avoid further contamination. Figure 2 presents the soil sampling points.

\section{Analysis of samples}

The different methods and norms used to analyze soils are summarized in Table 1.

\section{Assessment of contamination's degree and ecological risk of trace metals $(\mathrm{Cu}, \mathrm{Zn}, \mathrm{Hg}$,} As)

The geoaccumulation index (Igeo) was calculated as indicated by Equation 1. It estimate the degree of enrichment of each trace element in soils (Muller and Suess, 1979).

$$
\text { Igeo }=\log _{2}\left(\frac{\mathrm{C}_{g}}{1_{z} 5 \times \mathrm{C}_{\mathrm{ref}}}\right)
$$

Where:

$\mathrm{C}_{\mathrm{s}}$ is the total content of the individual element measured in this study,

$\mathrm{C}_{\mathrm{ref}}$ is its geochemical background concentration in the Upper Continental Crust (UCC),

1.5 is the background matrix correction factor due to lithogenic eff ects.

Seven classes of the geochemical index have been distinguished (Muller and Suess, 1979):

- Class 0 (uncontaminated): Igeo $\leq 0$;

- Class 1 (from uncontaminated to moderately contaminated): $0<$ Igeo $<1$;
- Class 2 (moderately contaminated): 1 $<$ Igeo $<2$;

- Class 3 (from moderately to strongly contaminated): $2<$ Igeo < 3 ;

- Class 4 (strongly contaminated): 3 $<$ Igeo $<4$;

- Class 5 (from strongly to extremely contaminated): $4<$ Igeo $<5$;

- Class 6 (extremely contaminated): Igeo $>5$.

The ecological risk index $\left(\mathrm{Er}^{i}\right)$ (Equation 2) was calculated to evaluate ecological risk of an individual metal (Hakanson, 1980).

$\mathrm{Er}^{i}=T_{r}^{i} \mathrm{x} \frac{\mathrm{c}_{\tilde{i}}}{\mathrm{C}_{\mathrm{ref}}}$

$\mathrm{C}_{i}$ is the concentration of metal $i$ in the soil, $\mathrm{C}_{\text {ref }}$ is background concentration of metal $i$ in the UCC, given by Wedepohl (1995);

$T_{r}^{i}$ is the biological toxicity factor of an individual element.

Referring to Hakanson (1980), $T_{r}^{\tilde{i}}$ values for As $=10 ; \mathrm{Cu}=5 ; \mathrm{Zn}=1$ and $\mathrm{Hg}=40$.

Hakanson (1980) categorized $\mathrm{Er}^{i}$ values into five potential ecological risk levels:

- $\mathrm{Er}^{i}<40$ : low risk,

- $40 \leq \operatorname{Er}^{i}<80$ : moderate risk,

- $80 \leq \mathrm{Er}^{i}<160$ : considerable risk,

- $160 \leq \mathrm{Er}^{i}<320$ : high risk,

- $\operatorname{Er}^{i} \geq 320$ : very high risk.

\section{Statistical analysis}

Statistical analysis of the data was performed with $\mathrm{R}$ software version 3.3.2. The normality of the data distribution and the homogeneity of the variances were verified respectively with the Shapiro test. To examine the differences between the concentrations of pollutants in the soil horizons as well as between the values of the physico-chemical parameters, data were analyzed using the parametric test (ANOVA test). Statistical significance was defined at the level of $\mathrm{P}<$ 0.05 . Concerning correlations of pollutants and physico-chemical parameters in soils, they were determined with Statistica 7.1 software. 


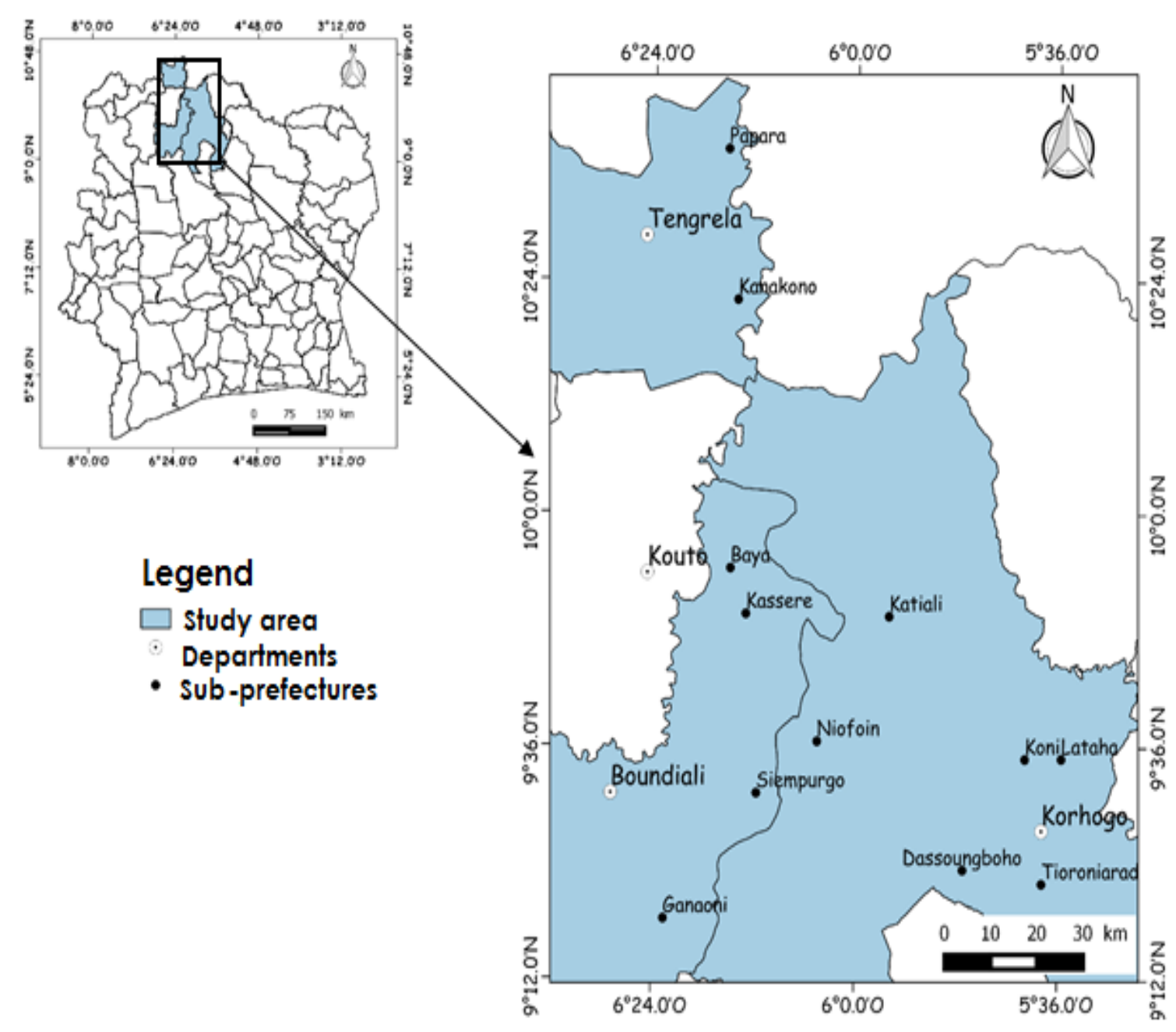

Figure 1: Location of the study area.

Table 1: Methods and norms for analysis of soil samples.

\begin{tabular}{|c|c|c|}
\hline Parameters & Methods of analysis & Norms \\
\hline$\overline{\text { pH }}$ & Measurement in soil solution using a $\mathrm{pH}$ meter & - \\
\hline CEC & Metson method & NFX 31-130: 1999 \\
\hline Organic matter & $\begin{array}{l}\text { Oxidation of carbon by potassium dichromate }\left(\mathrm{K}_{2} \mathrm{Cr}_{2} \mathrm{O}_{7}\right) \\
\text { in an acid medium }\end{array}$ & NF ISO $10694: 1995$ \\
\hline $\begin{array}{l}\text { Arsenic } \\
\text { Mercury } \\
\text { Zinc } \\
\text { Copper }\end{array}$ & $\begin{array}{l}\text { Aqua regia digestion of samples and reading on an } \\
\text { Atomic Emission Spectrometer coupled to Plasma }\end{array}$ & NF ISO $11466: 1995$ \\
\hline Cyanide & $\begin{array}{l}\text { Transformation of cyanide ions of samples into cyanogen } \\
\text { chloride and reading on a Visible UV spectrometry }\end{array}$ & NF T90-107 : 2002 \\
\hline
\end{tabular}





\begin{tabular}{l} 
Legend \\
- Departments \\
- Sub-prefectures \\
- Villages \\
Classified forest \\
- Sampling points \\
- Main roads \\
\hline
\end{tabular}

Figure 2: Sampling points of soils. $\mathrm{A}=$ Korhogo; $\mathrm{B}=$ Boundiali $\mathrm{C}=$ Tengrela . 


\section{RESULTS}

Impacts of artisanal and small-scale gold mining on the soil physical properties

Figure 3 show impacts of artisanal and small-scale gold mining on the soil physical properties. The main negative effects of artisanal gold mining observed in the study areas on soil physical properties were erosion and soil structure destruction (reversal of soils horizons, soil excavations).

\section{Soils physico-chemical parameter}

The values of the physicochemical parameters $(\mathrm{pH}$, organic matter and cation exchange capacity) decrease in the soil horizons with depth (Figure 4). The $\mathrm{pH}$ values range from 5.10 and 6.58 , from 5.19 to 6.24 , from 5.2 to 6.19 respectively in the soils of Boundiali, Korhogo and Tengrela. The $\mathrm{pH}$ values in soils horizons from all sites were not significantly different. The cation exchange capacity (CEC) varied between 4.20 and $22.12 \mathrm{meq} / 100 \mathrm{~g}$ at Boundiali, between 2.90 and $19.43 \mathrm{meq} / 100 \mathrm{~g}$ at Korhogo and between 4.00 and $24.00 \mathrm{meq} / 100 \mathrm{~g}$ at Tengrela. CEC values of soils horizon from Korhogo and Tengrela doesn't differ (P> $0.05)$. Conversely, soil horizons $[0-20 \mathrm{~cm}]$ and $[20-40 \mathrm{~cm}]$ present CEC values significantly higher than that of the $[40-60 \mathrm{~cm}]$ horizon $(\mathrm{P}$ $<0.05)$ on Boundiali site. Considering the similar soil horizons, we note that the average CEC values of the Tengrela soils are significantly higher than those of Korhogo and Boundiali $(\mathrm{P}<0.05)$. Concerning organic matter content, it ranged between 2.54 to $4.89 \%, 2.28$ to $4.87 \%, 2.86$ to $4.12 \%$, respectively in the soils of Boundiali, Korhogo and Tengrela. The average contents of organic matter do not differ significantly between the soil horizons $(\mathrm{P}>0.05)$ of studies areas. However, difference between the average organic matter contents of similar horizons in the Boundiali, Korhogo and Tengrela soils $(\mathrm{P}>0.05)$ were noted.
Concentrations of pollutants (copper, zinc, arsenic, mercury and cyanide) in soils

Trace metals (copper, zinc, arsenic, mercury) and cyanide concentrations in the soil horizons decrease with depth on all studied sites. Cyanide $(\mathrm{CN})$ concentrations ranged from 0.04 to $0.28 \mathrm{mg} / \mathrm{kg}$, from 0.01 to $0.32 \mathrm{mg} / \mathrm{kg}$ and from 0.002 to $0.12 \mathrm{mg} / \mathrm{kg}$, respectively in the soils of Boundiali, Korhogo and Tengrela. Considering the similar horizons of the different zones, cyanide concentrations of the soils do not differ significantly $(\mathrm{P}>0.05)$. Mercury $(\mathrm{Hg})$ concentrations ranged from $1.2 \times 10^{-4}$ to $6.61 \times$ $10^{-3} \mathrm{mg} / \mathrm{kg}$ in Boundiali, from $2 \times 10^{-4}$ to $5.1 \times 10^{-3} \mathrm{mg} / \mathrm{kg}$ at Korhogo and from $1.8 \times 10^{-4}$ and $9 \times 10^{-4} \mathrm{mg} / \mathrm{kg}$ at Tengrela. Mercury concentrations in similar horizons of sites were significantly difference $(\mathrm{P}<0.05)$, considering soils of Tengrela and those of Korhogo and Boundiali. The range of copper concentrations in the soils were $19.4-64.22$ $\mathrm{mg} / \mathrm{kg}$ in Korhogo, $20.4-73.1 \mathrm{mg} / \mathrm{kg}$ in Boundiali and $18.9-68 \mathrm{mg} / \mathrm{kg}$ at Tengrela. Moreover, no difference was observed between the $\mathrm{Cu}$ concentrations of similar horizons from all studied sites $(\mathrm{P}>0.05)$. As for Arsenic (As) concentrations, it ranged from 24.30 to $50.01 \mathrm{mg} / \mathrm{kg}$, from 17.80 to $41.60 \mathrm{mg} / \mathrm{kg}$, from 16.40 to $49.60 \mathrm{mg} / \mathrm{kg}$, respectively on Boundiali, Korhogo and Tengrela sites. The comparison of the average concentrations recorded on the three zones reveal no significantly difference $(\mathrm{P}>0.05)$. The ranges of zinc $(\mathrm{Zn})$ concentrations in the soils were 12.7 - $23.8 \mathrm{mg} / \mathrm{kg}$ (Boundiali), 10.2 - $23.5 \mathrm{mg} / \mathrm{kg}$ (Korhogo) and 14.3 - $26.6 \mathrm{mg} / \mathrm{kg}$ (Tengrela). In similar horizons of all studied sites, $\mathrm{Zn}$ concentration didn't differ significantly $(\mathrm{P}>0.05)$.

Correlations between pollutants and physico-chemical parameter in soils

Organic matter correlated positively with copper, zinc and cyanide (Table 2). There was no correlation between trace metals ( $\mathrm{Zn}, \mathrm{Cu}$ and $\mathrm{As}$ ). 
Assessment of contamination's degree and ecological risk of trace metals $(\mathrm{Zn}, \mathrm{Cu}, \mathrm{As}$, Hg)

The geoaccumulation index values of trace metals in soils collected from the three artisanal mining sites are shown in Table 3. $\mathrm{Hg}$ and $\mathrm{Zn}$ were uncontaminated in soils from Boundiali, Korhogo and Tengrela (Igeo $\leq 0$ ). Howover, most soils are strongly contaminated by As $(3<$ Igeo $<4)$. As for $\mathrm{Cu}$, it varied between uncontamination to moderate contamination and moderate contamination in the soils. In Boundiali, Korhogo and Tengrela areas, soils have ecological risk $\left(\mathrm{Er}^{i}\right)$ values ranged between 0.20 and 25.05 with $\mathrm{Cu}, \mathrm{Zn}$ and $\mathrm{Hg}$ (Table 4). Trace metals pose low ecological risk in soils contaminated with $\mathrm{Cu}, \mathrm{Zn}$ and $\mathrm{Hg}$. In contrast, As poses considerable to high ecological risk in soils.

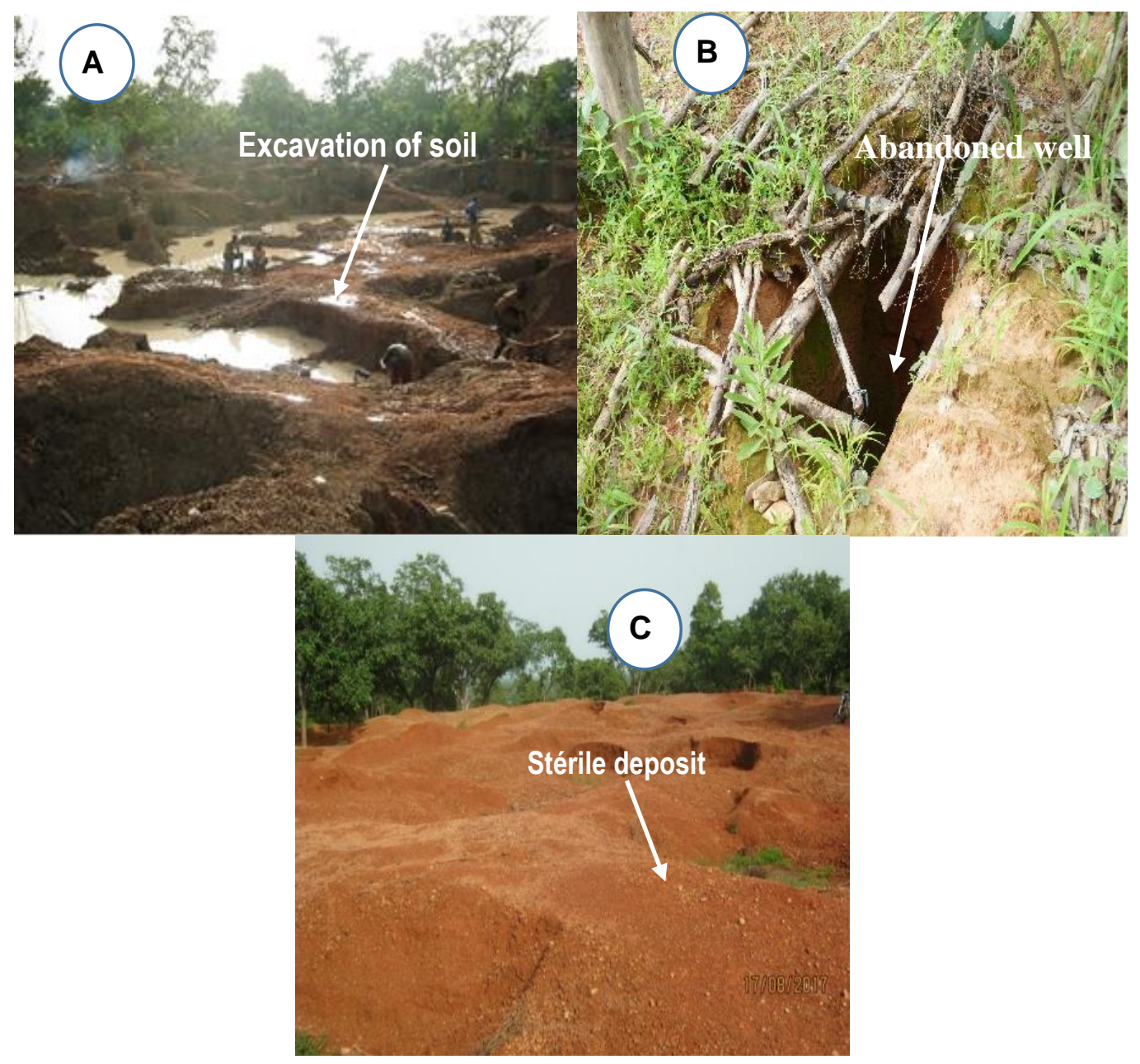

Figure 3: Illustrations of artisanal mining effects on soils.

$\mathrm{A}=$ excavation of the soil at Papara (Tengrela); $\mathrm{B}=$ abandoned well at Tiasso (Boundiali); $\mathrm{C}=$ turning the soil by sterile at Dasso (Tengrela). 

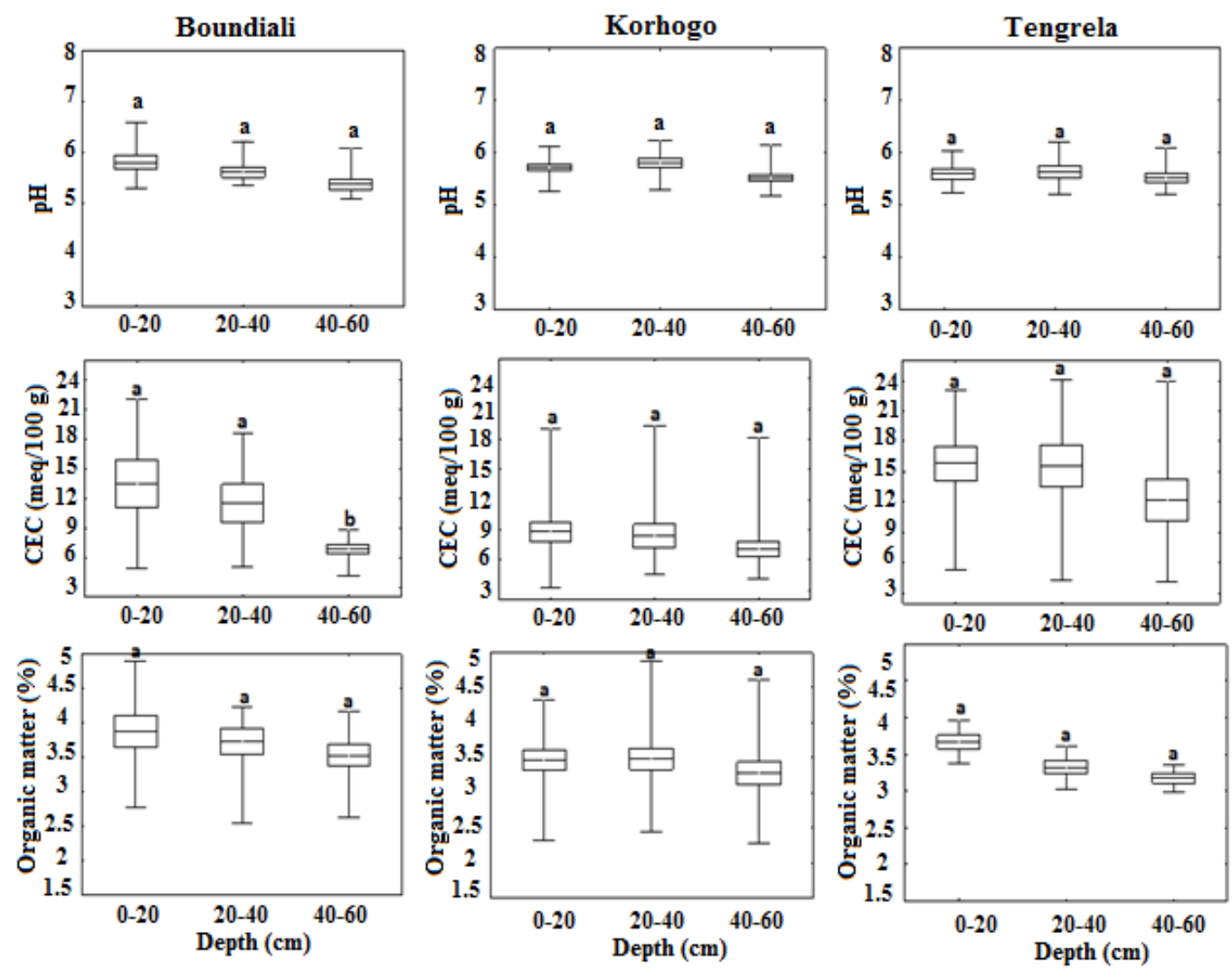

Figure 4: Variation in physico-chemical parameters $(\mathrm{pH}$, organic matter and cation exchange capacity) of soils at artisanal mining sites in Boundiali, Korhogo and Tengrela.

Box-plot marked with common letters do not differ significantly according to ANOVA test at P $>0.05$.

Table 2: Pearson's correlation matrix of pollutants and physico-chemical parameters in soils.

\begin{tabular}{|c|c|c|c|c|c|c|c|c|c|}
\hline $\begin{array}{c}\text { Sampling } \\
\text { area }\end{array}$ & Parameters & $\mathbf{C u}$ & As & $\mathbf{Z n}$ & $\mathbf{C N}$ & Hg & $\mathbf{O M}$ & pH & CEC \\
\hline \multirow{8}{*}{ Korhogo } & $\overline{\mathbf{C u}}$ & 1 & & & & & & & \\
\hline & As & -0.07 & 1 & & & & & & \\
\hline & Zn & -0.28 & -0.10 & 1 & & & & & \\
\hline & $\mathrm{CN}$ & 0.40 & -0.04 & 0.10 & 1 & & & & \\
\hline & Hg & 0.39 & 0.20 & -0.30 & 0.08 & 1 & & & \\
\hline & MO & 0.47 & 0.08 & 0.43 & 0.48 & 0.10 & 1 & & \\
\hline & pH & 0.19 & -0.07 & 0.05 & 0.14 & -0.32 & 0.34 & 1 & \\
\hline & CEC & -0.41 & 0.43 & 0.01 & -0.17 & 0.07 & 0.48 & -0.34 & 1 \\
\hline \multirow{9}{*}{ Boundiali } & $\overline{C u}$ & 1 & & & & & & & \\
\hline & As & 0.03 & 1 & & & & & & \\
\hline & Zn & 0.71 & 0.28 & 1 & & & & & \\
\hline & $\mathbf{C N}$ & 0.58 & -0.06 & 0.40 & 1 & & & & \\
\hline & $\mathrm{Hg}$ & 0.59 & -0.24 & 0.53 & 0.61 & 1 & & & \\
\hline & MO & 0.61 & -0.07 & 0.86 & 0.85 & 0.28 & 1 & & \\
\hline & pH & -0.06 & 0.50 & 0.14 & 0.12 & -0.04 & 0.20 & 1 & \\
\hline & CEC & 0.32 & -0.13 & 0.28 & 0.50 & 0.33 & 0.37 & 0.05 & 1 \\
\hline & \multicolumn{9}{|c|}{1241} \\
\hline
\end{tabular}




\begin{tabular}{llcccccccc}
\hline & Cu & 1 & & & & & & & \\
& As & 0.13 & 1 & & & & & & \\
& Zn & $\mathbf{0 . 6 5}$ & 0.38 & 1 & & & & & \\
Tengrela & CN & $\mathbf{0 . 4 5}$ & 0.11 & 0.39 & 1 & & & & \\
& Hg & 0.21 & 0.31 & 0.06 & 0.36 & 1 & & & \\
& MO & $\mathbf{0 . 4 5}$ & 0.33 & $\mathbf{0 . 5 1}$ & $\mathbf{0 . 6 3}$ & $\mathbf{0 . 5 6}$ & 1 & & \\
& pH & 0.06 & -0.21 & -0.09 & -0.12 & -0.04 & -0.24 & 1 & \\
& CEC & -0.15 & $\mathbf{0 . 5 6}$ & -0.03 & 0,17 & $\mathbf{0 . 5 6}$ & $\mathbf{0 . 5 1}$ & -0.02 & 1 \\
\hline
\end{tabular}

$\mathrm{Zn}=$ zinc; $\mathrm{Cu}=$ copper; $\mathrm{As}=$ arsenic; $\mathrm{Hg}=$ mercury; $\mathrm{CN}=$ cyanide; $\mathrm{OM}=$ organic matter and $\mathrm{CEC}=$ cation exchange capacity; Bold values are significant at $\mathrm{p}<0.05$.

Table 3: Geo-accumulation Index (Igeo) in soils.

\begin{tabular}{|c|c|c|c|c|c|}
\hline Sampling area & Sampling point & As & $\mathbf{C u}$ & $\mathbf{Z n}$ & $\mathrm{Hg}$ \\
\hline \multirow{17}{*}{ Korhogo } & P1 & 3.32 & 0.38 & -2.01 & $-5,39$ \\
\hline & P2 & 2.93 & 1.10 & -2.30 & $-4,28$ \\
\hline & P3 & 3.46 & 0.83 & -2.38 & $-4,67$ \\
\hline & P4 & 3.38 & 0.42 & -2.04 & $-8,18$ \\
\hline & P5 & 3.46 & 0.60 & -2.13 & $-4,81$ \\
\hline & P6 & 3.07 & 0.95 & -1.88 & $-4,43$ \\
\hline & P7 & 3.24 & 1.30 & -2.77 & $-7,38$ \\
\hline & P8 & 3.51 & 1.38 & -2.04 & -4.30 \\
\hline & P9 & 2.98 & 0.32 & -2.12 & -7.80 \\
\hline & P10 & 3.64 & 0.06 & -2.35 & -6.96 \\
\hline & P11 & 3.44 & 0.04 & -2.34 & -8.48 \\
\hline & P12 & 3.19 & 0.73 & -2.06 & -7.31 \\
\hline & P13 & 3.21 & 0.67 & -2.02 & -6.99 \\
\hline & P14 & 3.21 & 0.80 & -2.02 & -7.27 \\
\hline & P15 & 3.01 & 0.97 & -1.95 & -7.79 \\
\hline & P16 & 3.10 & 1.46 & -2.16 & -7.21 \\
\hline & P17 & 3.01 & 0.56 & -2.18 & -7.88 \\
\hline \multirow{9}{*}{ Boundiali } & $\overline{\mathrm{P} 18}$ & 3.53 & 1.74 & -1.84 & -4.25 \\
\hline & P19 & 3.37 & 1.67 & -1.86 & -3.81 \\
\hline & P20 & 3.47 & 1.25 & -1.94 & -5.84 \\
\hline & P21 & 3.44 & 0.03 & -2.16 & -7.71 \\
\hline & P21 & 3.59 & 0.02 & -2.44 & -7.50 \\
\hline & P23 & 3.66 & 1.57 & -1.96 & -6.85 \\
\hline & P24 & 3.87 & 1.21 & -1.92 & -6.09 \\
\hline & P25 & 3.38 & 1.42 & -2.16 & -5.32 \\
\hline & P26 & 3.07 & 1.22 & -2.09 & -5.78 \\
\hline \multirow{10}{*}{ Tengrela } & P27 & 3.25 & 1.02 & -2.25 & -7.05 \\
\hline & $\mathrm{P} 28$ & 3.30 & 0.22 & -2.34 & -6.91 \\
\hline & P29 & 3.09 & 1.18 & -2.11 & -7.84 \\
\hline & P30 & 3.19 & 1.21 & -1.76 & -7.95 \\
\hline & P31 & 3.00 & 0.42 & -2.34 & -8.08 \\
\hline & P32 & 3.11 & 0.04 & -2.26 & -8.25 \\
\hline & P33 & 3.99 & 1.06 & -1.78 & -7.67 \\
\hline & P34 & 3.87 & 0.46 & -2.16 & -7.20 \\
\hline & P35 & 3.97 & 1.02 & -1.98 & -7.53 \\
\hline & P36 & 3.14 & 1.51 & -1.74 & -7.31 \\
\hline
\end{tabular}

Uncontaminated

Moderately contaminated

Strongly contaminated
Uncontaminated to moderately contaminated

Moderately to strongly contaminated 
Table 4: Ecological risk of trace metals $(\mathrm{Cu}, \mathrm{Zn}, \mathrm{Hg}, \mathrm{As})$.

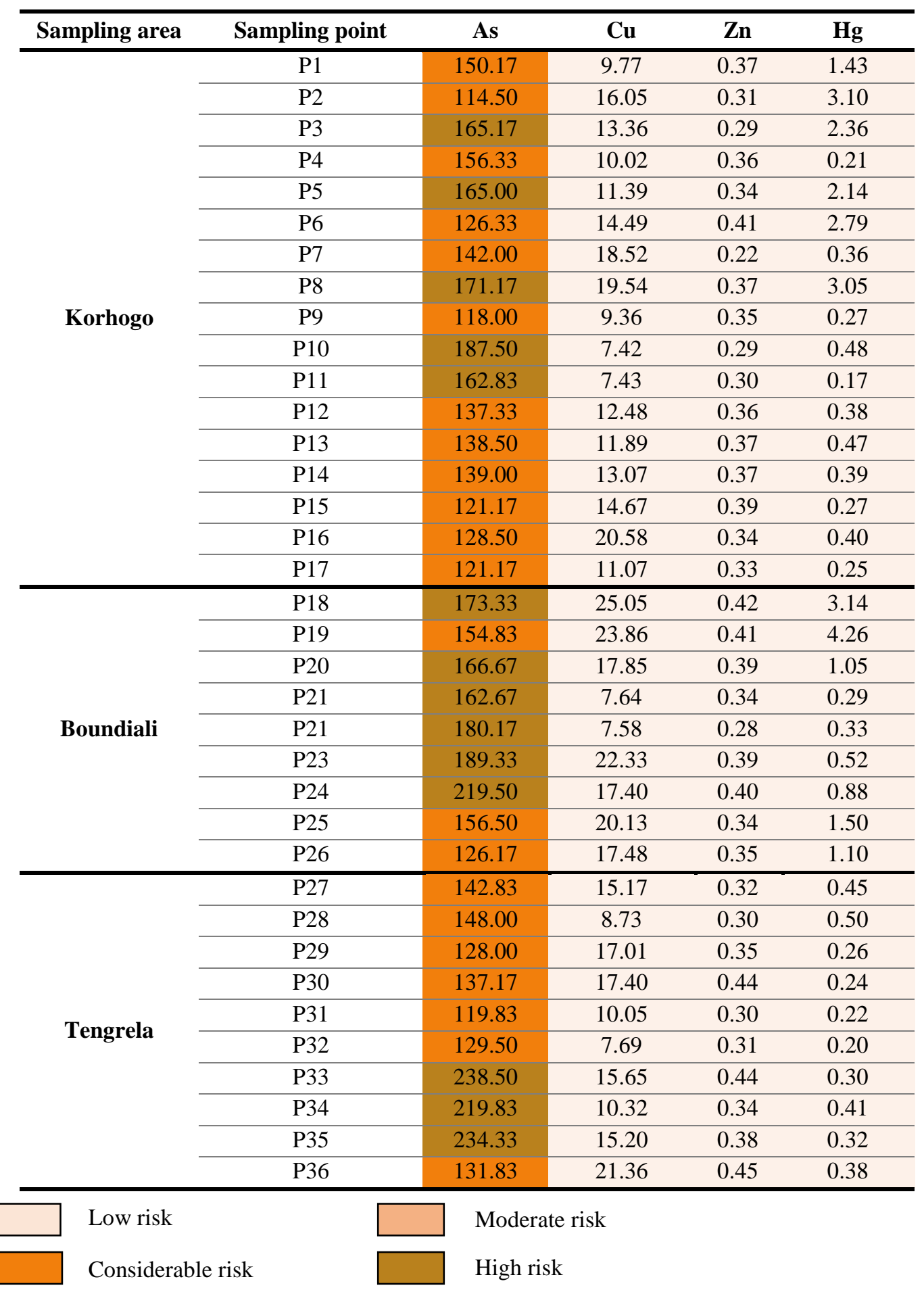



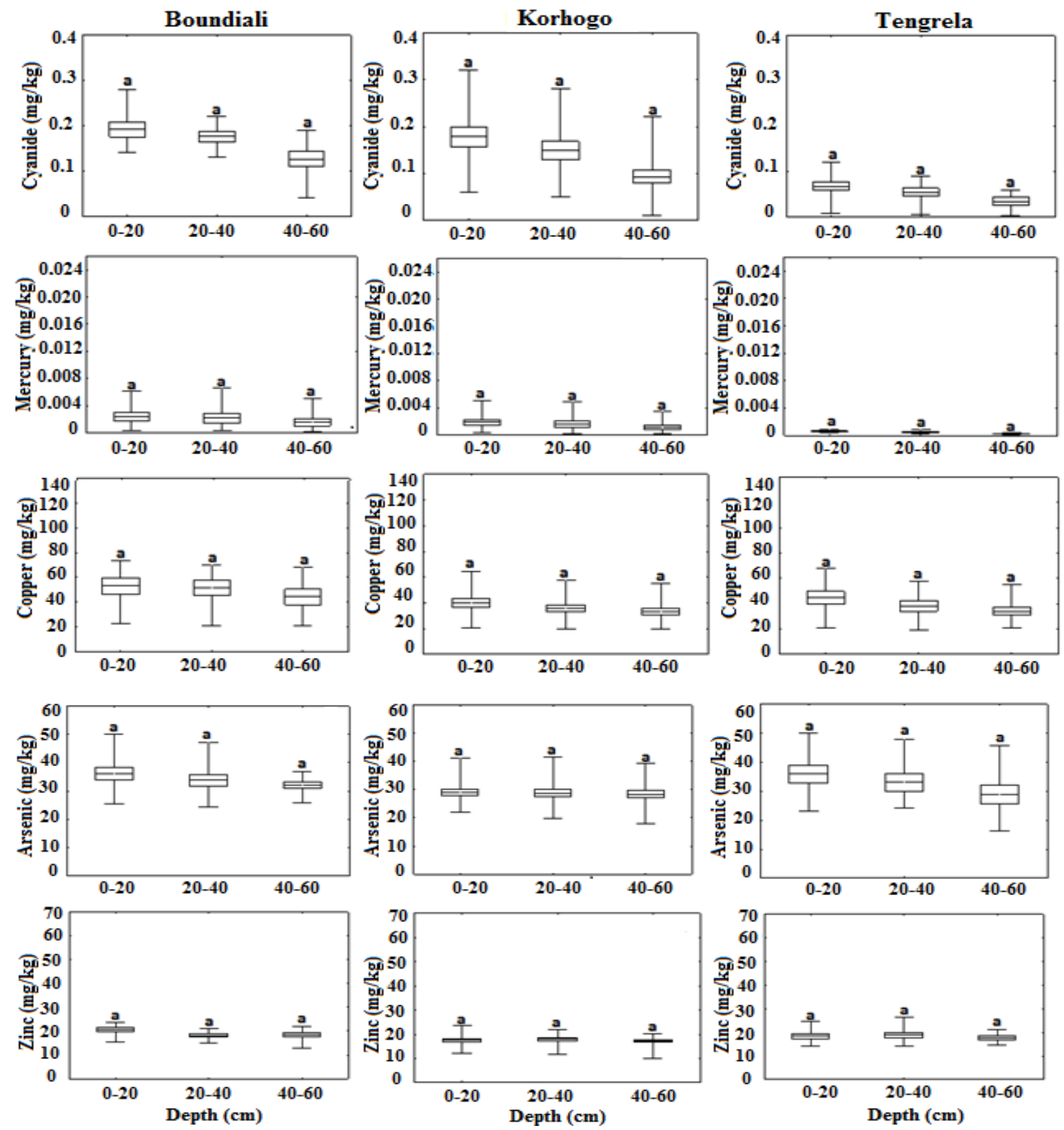

Figure 5: Variation of zinc, copper, arsenic, mercury and cyanide in the soils studied.

Box-plot marked with common letters do not differ significantly according to ANOVA test at $\mathrm{P}>0.05$.

\section{DISCUSSION}

The study carried out in the Korhogo, Boundiali and Tengrela areas permitted to note the impact of artisanal mining on the soil. The main negative effects of artisanal gold mining on soil physical properties were erosion, destruction of the soil structure.
These same impacts have been observed by on artisanal mining sites at Bouna (Wandan et al., 2015) and Hiré (Kouadio, 2012). To operate, the artisanal miners cut the plants to get enough space to carry out their activity. This deforestation exposes soil to erosion. Wells and excavations contribute to an irreversible 
degradation of the soils since these are not reconstituted at the end of the activities. Soil degradation and loss of important soil nutrients in the area cause by artisanal mining activities could induce the reduction of agricultural production and constitute a major threat to qualitative food security and sustainable livelihoods in the area (Adebayo et al., 2017). The $\mathrm{pH}$ values indicate that soils were acid. Indeed, phenomena such as the leaching of the soil, losses of mineral reserves and those of the power of retention during pedogenesis, losses of basic cations by leaching and by erosion after clearing, constitute causes of the acidification of soils (Blanchard, 2010). Koulibaly et al. (2014) extend soil acidification to all the phenomena of soil degradation: loss of structure, organic matter, release of toxic elements. The soils of studies areas show generally low organic matter content. This could be explained that by deforestation and soil erosion at the artisanal gold mining sites. Indeed, the destruction of the plant cover, the excavations and the overturning of the soil cause a loss of the nutritive elements and the organic matter of the soil in rainy events (Diallo et al., 2020). Our results were in line with a previous study reporting low organic matter content in metal contaminated soils. Concentrations of pollutants $(\mathrm{Cu}, \mathrm{Zn}, \mathrm{As}, \mathrm{Hg}$ and $\mathrm{CN})$ in the soil horizons decrease with depth on all studied sites. According to Baize (2010), such a contamination profile comes from anthropogenic pollution. The mean concentrations of $\mathrm{Cu}, \mathrm{Zn}, \mathrm{Hg}$ and $\mathrm{CN}$ in soils are below Canadian Council of Ministers of the Environment (CCME) standard (250 $\mathrm{mg} / \mathrm{kg}$ for $\mathrm{Zn}, 6.6 \mathrm{mg} / \mathrm{kg}$ for $\mathrm{Hg}, 63 \mathrm{mg} / \mathrm{kg}$ for $\mathrm{Cu}$ and $0.9 \mathrm{mg} / \mathrm{kg}$ for $\mathrm{CN}$ ) (CCME, 2020). On the other hand, As concentrations are above CCME standard (12 mg/kg) (CCME, 2020). Relatively $\mathrm{Zn}, \mathrm{Cu}$ and $\mathrm{CN}$, these are correlated positively with organic matter. This correlation allows us to state that these pollutants are governed by the same adsorption mechanism, in particular the retention on organic matter. So, the low levels of pollutants' contamination $(\mathrm{Zn}, \mathrm{Cu}, \mathrm{CN})$ would be due to soil erosion which would have drained the pollution on the artisanal mining sites studied. Concerning the low concentrations of $\mathrm{Hg}$ recorded in the studied soils, they would be due to the high volatility of this chemical element. Indeed, during the amalgamation process of gold ores, significant amounts of $\mathrm{Hg}$ can be emitted to the atmosphere by volatilization (YVE, 2012). Moreover, mercury is eliminated in soils after microbial reduction of $\mathrm{Hg}^{2+}$ to $\mathrm{Hg}(0)$ (Lloyd, 2003) or after photo-reduction (Eriksen et al., 2003). The high concentrations of arsenic found in soils are believed to be due to the high affinity of this pollutant with gold, but also to the nature of the soils studied and the climatic conditions in the different areas. Indeed, although it is present in very varied deposits because it is linked to metals (gold, lead, zinc, copper, etc.), arsenic is particularly present in high proportions in gold ores, up to $110 \mathrm{~g} / \mathrm{kg}$. The main arsenic-bearing mineral in ores is arsenopyrite (Lombi et al., 2000). The retention mechanism of arsenic in soils is mainly by adsorption on iron hydroxides and oxides contained in minerals (hematite, goethite) associated with kaolinite in soils (Pedron, 2004). In regions with a tropical climate with a marked dry season, to which belongs, Boundiali, Korhogo, Tengrela, there is a strong accumulation of iron oxides in the soil (Bohi, 2008). These iron oxides would have adsorbed arsenic and thus favored a high concentration of As in the soils. Considering the geoaccumulation index values, most soils are strongly contaminated by As $(3<$ Igeo < 4). According to the classification of Hakanson (1980), As poses considerable to high ecological risk in soils. As can cause inhibition of germination, growth, photosynthetic activity, deoxyribonucleic acid damage, root system changes, chlorosis and necrosis in plants (Li et al., 2007). The 
ingestion of products contaminated by As can cause abdominal pain, hyperpigmentation of the skin, vomiting, diarrhea, cholera and cancers of the skin, bladder, lungs, kidneys and stomach liver (National Institute for Industrial Environment and Risks, 2007).

\section{Conclusion}

This study assessed the impact of artisanal mining on the soils in the Korhogo, Boundiali and Tengrela areas. It appears that artisanal mining activity negatively affects the physical properties of the soil (destruction of the topsoil, modification of the soil structure and soil erosion). Analysis of the samples collected showed that the soils had an overall acid $\mathrm{pH}$ and low organic matter contents (from 2.28 to $4.89 \%$ in Boundiali, 2.28 to $4.87 \%$ in Korhogo, 2.86 to $4.12 \%$ at Tengrela). CEC values varied between 4.20 and $22.12 \mathrm{meq} / 100 \mathrm{~g}$ in Boundiali, between 2.90 and $19.43 \mathrm{meq} / 100 \mathrm{~g}$ in Korhogo and between 4.00 and $24.00 \mathrm{meq} / 100 \mathrm{~g}$ at Tengrela. Soils are contaminated with pollutants such as $\mathrm{Hg}\left(1.210^{-4}-5.110^{-3}\right.$ $\mathrm{mg} / \mathrm{kg}), \mathrm{CN}(0.002-0.32 \mathrm{mg} / \mathrm{kg}), \mathrm{Cu}(18.90-$ $73.10 \mathrm{mg} / \mathrm{kg}$ ), As (16.40 - 50.1 mg/kg) and $\mathrm{Zn}$ (10.20 - $26.60 \mathrm{mg} / \mathrm{kg})$. Geo-accumulation index in soils showed uncontamination in $\mathrm{Hg}$ and $\mathrm{Zn}$, uncontamination to moderate contamination in $\mathrm{Cu}$ and moderately to strongly contamination in As. Element As may pose high risks to biota base on the results of combined ecological risk index and CCME standard.

\section{COMPETING INTERESTS}

The authors declare that they have no competing interests.

\section{AUTHORS' CONTRIBUTIONS}

JCAB, AM, JMPO conducted data collection, data processing and drafting of the manuscript, while LC supervised the study.

\section{ACKNOWLEDGMENTS}

This study has been supported by SidaUNESCO project on abandoned mines in subSaharan African countries. We are very grateful to the Minister in charge of Mines for data, permission to access and sampling. We thank the Sanitation and Environmental Engineering research team members for their help during the field data collecting.

\section{REFERENCES}

ACET. 2017. The impact of expanding artisanal and small-scale mining on small holder agriculture in West Africa: a case study of Burkina Faso, Ghana and Sierra Leone. ACET Synthesis Report, $41 \mathrm{p}$.

Adebayo OE, Abosede TO, Temitope OO, Olusegun OA. 2017. Effects of artisanal gold mining activities on soil properties in a part of southwestern Nigeria. Cogent Environ. Sci., 3: 1-11. DOI: 10.1080/23311843.2017.1305650

Akpo S, Koné T, Coulibaly L, Mahamadou K, Coulibaly L. 2020. Diagnostics of environmental risks and mapping of surface water sensitivity due to metal contamination from artisanal gold mining in Côte d'Ivoire: case of Angovia, Kokumbo, Hire and Agbaou. Journal of Geoscience and Environment Protection, $\quad 8: \quad 47-64$. DOI: $10.4236 /$ gep.2020.82004

Baize D. 2010. Total lead content as a function of depth in "natural" soils. Archeo. Sciences, 34: 127-135. DOI: 10.4000/archeosciences. 2709

Blanchard M. 2010. Soil fertility management and the role of the herd in cotton-cereallivestock systems in southern Mali. Local technical knowledge and agricultural-livestock integration practices. PhD Thesis, Paris-Est University, Paris, 298 p.

Bohi ZPB. 2008. Characterization of lateritic soils used in road construction: the case of the Agneby region (Côte d'Ivoire). 
Ph.D Thesis, Paris Tech University, Paris, $142 \mathrm{p}$.

Brou Y. 2005. Climate, socio-economic changes and landscapes in Côte d'Ivoire. Master's Dissertation, University of Sciences and Technologies of Lille, Lille, $106 \mathrm{p}$.

CCME. 2020. Soil quality guidelines for the protection of environmental and human health. CCME, Canada. http://stts.ccme.ca/en/index.html

Dan-Badjo TA, Tidjani D, Idder T, Guero Y, Dan LN, Matsallabi A, Echevarria G. 2014. Diagnostic de la contamination des eaux par les éléments traces métalliques dans la zone aurifère de Komabangou Tillabéri, Niger. Int. J. Biol. Chem. Sci., 8(6): 2849-2857. DOI: 10.4314/ijbcs.v8i6.41

Diallo A, Wade F, Kourouma S. 2007. Effects of artisanal gold mining on forest resources in Siguiri. Higher Agronomic and Veterinary Institute Valéry Giscard d'Estaing, University of Conakry, Guinea Conakry, 32 p.

Ericksen JA, Gustin MS, Schorran DE, Johnson DW, Lindberg SE, Coleman JS. 2003. Accumulation of atmospheric mercury in forest foliage. Atmos. Environ., 37(12): 1613-1622. DOI: 10.1016/S1352-2310(03)00008-6

Goh D. 2016. Artisanal gold mining in Côte d'Ivoire: the persistence of illegal activity. Eur. Sci. J., 12(3): 18-36. DOI: 10.19044/esj.2016.v12n3p18

Goula BTA, Konan B, Brou YT, Savane I, Fadika V, Srohourou B. 2007. Estimation of exceptional daily rainfall in tropical zone: case of Côte d'Ivoire by comparison of log normal and Gumbel laws. Hydrolog. Sci. J., 52(1): 49-67. DOI: $10.1623 /$ hysj.52.1.49

Hakanson L. 1980. Ecological risk index for aquatic pollution control: a sedimentological approach. Water Res.,
14(5): $\quad 975-1001 . \quad$ DOI: 10.1016/00431354(80)90143-8

Hinton JJ, Veiga MM, Beinhoff C. 2003. Women, mercury and artisanal gold mining: risk communication and mitigation. J. Phys., 4: 617-620. DOI: 10.1051/jp4:20020379

Ibrahim OZ, Dan-Badjo AT, Guero Y, Idi MMF, Feidt C, Sterckeman T, Echevarria G. 2019. Distribution spatiale des éléments traces métalliques dans les sols de la zone aurifère de Komabangou au Niger. Int. J. Biol. Chem. Sci., 13(1): 557-573. DOI: 10.4314/ijbcs.v13i1.43

Keita S. 2001. Study on Artisanal Mines and Small-scale Mining in Mali. IIED: London.

Konaté D. 2016. Fish contamination on artisanal gold mining area and health risks: case of in Hiré (Côte d'Ivoire). Master's Dissertation, Nangui Abrogoua University, Abidjan, 55 p.

Kouadio N. 2012. Artisanal gold mining in Hiré. Newcrest Report, Abidjan-Cote d'Ivoire, $81 \mathrm{p}$.

Koulibaly B, Traore O, Dakuo D, Lalsaga R, Lompo F, Zombre P. 2014. Acidification des sols ferrugineux et ferrallitiques dans les systèmes de production cotonnière au Burkina Faso. Int. J. Biol. Chem. Sci., 8(6): $\quad 2879-2890 . \quad$ DOI: 10.4314/ijbcs.v8i6.44

Li CX, Feng SL, Shao Y, Jiang LN, Lu XY, Hou XL. 2007. Effects of arsenic on seed germination and physiological activities of wheat seedlings. J. Environ. Sci., 19: 725-732. DOI: 10.1016/s10010742(07)60121-1

Lloyd JR. 2003. Microbial reduction of metals and radionuclides. FEMS Microbiol. Rev., 27(2-3): 411-425. DOI: 10.1016/S0168-6445(03)00044-5

Lombi E, Wenzel WW, Adriano DC. 2000. Arsenic-contaminated soils. In Remediation Engineering of Contaminated Soils, Wise DL, Trantolo 
DJ, Cichon EJ, Inyang HI, Stottmeister U (eds). Dekker: New York; 739-758.

Müller PJ, Suess E. 1979. Productivity, sedimentation rate, and sedimentary organic matter in the oceans-I. Organic carbon preservation. Deep. Sea. Res. A., 26(12): 1347-1362. DOI: 10.1016/01980149(79)90003-7

National Institute for Industrial Environment and Risks. 2007. Development of new toxicological reference values for Arsenic. INERIS, Paris.

Ouattara H. 2015. Contribution to the study of the contamination of lake Kossou in the District of Yamoussoukro by gold mining activities. Master's Dissertation, Nangui Abrogoua University, Abidjan, $60 \mathrm{p}$.

Pedron V. 2004. Study of the physicochemical and microbiological processes of elimination of arsenic in a process of biological iron removal. Master's Dissertation, Montpellier II University, Montpellier, $96 \mathrm{p}$.

RGPH. 2014. Implementation and presentation report of the main results of the general population and housing census. RGPH Report, Abidjan-Côte d'Ivoire, $26 \mathrm{p}$.

Tape ASB, Coulibaly A, Anoh PK, Aloko JN. 2019. Waste production and workers' health: case of the Tongon Gold Mine (Côte d'Ivoire). Eur. Sci. J., 15(32): 104118. DOI: 10.19044/esj.2019.v15n32p104

Wandan E, Koffi G, Kouadio K, Gomba D. 2015. Environmental evaluation of small scale gold mining in the Bounkani region in the upper east area of Côte d'Ivoire. IJEMA, 3(5): 265-274. DOI: 10.11648/j.ijema.20150305.14

Wedepohl KH. 1995. The composition of the continental crust. Geochim. Cosmochim. Acta, 59: 1217-1232. DOI: 10.1016/0016-7037(95)00038-2

Yapi H, Dongui B, Trokourey A, Barima Y, Essis Y, Atheba P. 2014. Evaluation de la pollution métallique des eaux souterraines et de surface dans un environnement minier aurifère à Hiré (Côte d'Ivoire). Int. J. Biol. Chem. Sci., 8(3): $\quad 1281-1289 . \quad$ DOI: 10.4314/ijbcs.v8i3.41

YVE (Young Volunteers for the Environment). 2012. Qualitative assessment of atmospheric mercury emissions in Côte d'Ivoire: case of certain artisanal gold mining sites and certain health centers. YVE Report, Abidjan, Cote d'Ivoire, $54 \mathrm{p}$. 